\title{
PURULENT TYPHOID MENINGITIS
}

\author{
REPORT OF A CASE
}

\author{
E. A. BaUmgartxer, Ph.D., M.D., and H. H. OLSEN, M.D. \\ HALSTEAD, KAN.
}

Meningitis due to the B. typhosus is a relatively rare disease. Cole collected the cases recorded up to 1904. We have been able to find twenty-three cases recorded in the literature since that time.

In addition to reviewing the cases reported by Cole, we wish to report a case in which cholecystitis and otitis media were additional complications. We had the opportunity of doing a necropsy in this case, thus making an anatomic study of the complications possible. The findings of the meningeal complication and of a pure typhoid culture comply with all of Cole's requirements for the diagnosis of purulent meningitis.

\section{REPORT GF CASE}

Case 3494.-R. A., aged 6, admitted to the Halstead Hospital, Oct. 12, 1919, with complaint of headache, fever and abdominal pain.

Family History--Negative. One brother living and well. The brother later developed typhoid fever and was a patient in the hospital. Positive Widal; no complications.

Personal History.-When 3 years old, the patient had swollen glands on both sides of neck, not associated with pain or redness, but tender. These swellings disappeared in about four weeks. Patient had an acute tonsillitis when 5 years of age.

P'resent History.-The patient had an attack of diarrhea, October 6. On the afternoon of the seventh, he complained of abdominal pain. Two days later he was seen by a physician. On the second day the patient's temperature was $102 \mathrm{~F}$. October 12, it was $105 \mathrm{~F}$.

The boy was brought to the hospital the evening of October 12 . He was seen for the first time by our staff. His temperature was 105.8, pulse 150, leukocyte count 9,000. His head, neck and chest were negative. His abdomen was somewhat distended and tender. The spleen was not definitely palpable, nor were any other masses found. There was painful urination. The urine was slightly clouded, and showed a trace of albumin; otherwise it was negative.

During the night he was restless, thirsty, expelled much flatus and several watery stools, with mucus. The next day the patient was delirious, the temperature remaining above $104 \mathrm{~F}$; the pulse rate was about 120 . On the following three days, he was quite restless, at times passing urine and feces involuntarily. He was delirious and picked at the bed clothes. At times he was noisy, complained of stiffness of his legs, pain in his throat and difficult deglutition. His temperature slowly came down. The spleen was now definitely palpable, but at no time were rose spots noted.

On the sixth day his temperature reached $101 \mathrm{~F}$. He had some epistaxis on this day and later passed several dark red stools which showed blood. He seemed more quiet and rational, but complained of pain on voiding urine and when his bowels moved. During the following days his temperature remained between $100 \mathrm{~F}$, and $102 \mathrm{~F}$; pulse, 104 to 130 . On the eleventh day, 
the temperature again rose to $104 \mathrm{~F}$; p pulse was about the same. Voiding and passing of stools was painful; the patient was restless and crying. A mass, soft and fluctuating, had been noticed in the right subcostal region two days earlier. This had increased until it reached the level of the' umbilicus and was plainly visible. The leukocytes numbered 17,400 .

Diagnosis.-Acute cholecystitis was diagnosed.

Opcration.-In the afternoon an operation was performed. The gallbladder was very much enlarged, extending below the umbilicus; its vessels were congested, walls thin and almost transparent. About 70 c.c. of a rather thin, slimy, greenish bile was evacuated, and then a greenish yellow fluid was found. Smears showed only a very few epithelial-like cells. The culture was negative.

Subsequent Course--During the next three days, the temperature ranged from 103 to $104.5 \mathrm{~F}$.; pulse, 120 to 134 . The patient was restless, crying and very thirsty. On the sixteenth day, his neck was stiff and the head was drawn back. There was involuntary passage of urine and stools. The throat contained much phlegm. A yellowish discharge came from the left ear. The pulse ranged between 116 and 132. On the evening of the seventeenth day, at $6 \mathrm{p} . \mathrm{m}$., the patient had a convulsion, lasting about twenty-five minutes, during which the temperature rose to $107 \mathrm{~F}$., pulse to 140 . The pupils were markedly dilated. The patient was cyanotic.

The next day the patient was restless; the muscles of the face were twitching, temperature 103 to $106 \mathrm{~F}$.; pulse, 120 to 150 ; neck stiff; Kernig positive, knee jerks somewhat increased. Spinal puncture showed fluid under pressure, cloudy; about 15 c.c. was removed. Cell count, 400, mostly mononuclears. Smear: gram-negative, short bacilli, slightly motile; mononuclear cells. Culture; motile bacilli, gram-negative.

On the eighteenth day, the patient was quieter; cyanotic; temperature, 105 to $105.5 \mathrm{~F}$; pulse weak, 140 to 156 , but difficult to count; blood tinged mucus in throat.

Patient died at 2 p. $\mathrm{m}$.

A spinal puncture at $2: 30 \mathrm{p} . \mathrm{m}$. showed fluid not under increased pressure, turbid, about 15 c.c. Cell count, 400, mostly mononuclears. Smear: gramnegative, short bacilli; Ross Jones slightly positive. Culture: hanging drop, motile bacilli, gram-negative.

liccropsy.-Four p. m. Body, that of a white boy, about 5 or 6 years old, fairly good build, nutrition fair, small bruises over left internal malleolus, and external surface right ankle. Operation wound with rubber tube drain in upper right abdomen. Pupils, $3 \mathrm{~mm}$.; equal.

Brain: Meninges somewhat injected; on removing dura brain surface of frontal lobe covered with thin, pale yellow, cloudy film (Figs. 1 and 2). A collection of pus (?) in posterior fossa between cerebellum and medulla.

Abdomen: No free fluid in abdomen. Omentum well walled about gallbladder region.

Stomach and Intestines: About 36 inches below pylorus, a short intussusception, of about 2 inches, existed. Below this, a large amount of tarry stool filled about 2 feet of the intestine. On section, no ulcers observed, except near ileocecal valve, where the mucosa was markedly reddened, and studded with minute ulcerations. Lymph nodes in mesentery, especially near intestine, are markedly enlarged, measuring $1 \mathrm{~cm}$. and more in length and from 0.5 to 0.7 c.c. in thickness.

Liver and gallbladder appeared to be quite normal. Gallbladder shrunk to about $6 \mathrm{~cm}$. in length and in diameter to the size of the rubber tube drain placed at operation. Wall not thickened. Liver on section normal. Cystic and common duct appear normal in size and structure; no obstruction present.

Spleen: Increased in size 10.5 by 8.5 by 4 , weight, $146 \mathrm{gm}$. Splenic nodules show prominently in section. 
Kinneys: Fatty capsule, comparatively thin; capsule strips easily from both. Left kidney, 10 by 6.5 by 4.5 , weight, $163 \mathrm{gm}$. Right kidney, 9 by 5 by 3 , weight, $84 \mathrm{gm}$. Cortex about from 5 to $8 \mathrm{~mm}$. thick in both kidneys. Pelves both markedly dilated as are the ureters at the lower end. Both stood out prominently, measuring about 8 or $10 \mathrm{~mm}$. diameter from pelvic brim to the bladder. Probe passed easily to the bladder.

Heart and Lungs: Not taken.

Microscopical: Brain shows meninges (except dura) markedly infiltrated with polymorphonuclear leukocytes and other cells (Fig. 3). This infiltration follows the vessels only a short distance into the cortex.

On closer examination it is seen that many of the cells in the meninges are not polymorphic cells but large plasmalike cells, some about 15 microns in diameter, markedly vacuolated, with small reddish stained inclusion particles, possibly red cells, the nuclei more or less eccentrically placed, rather

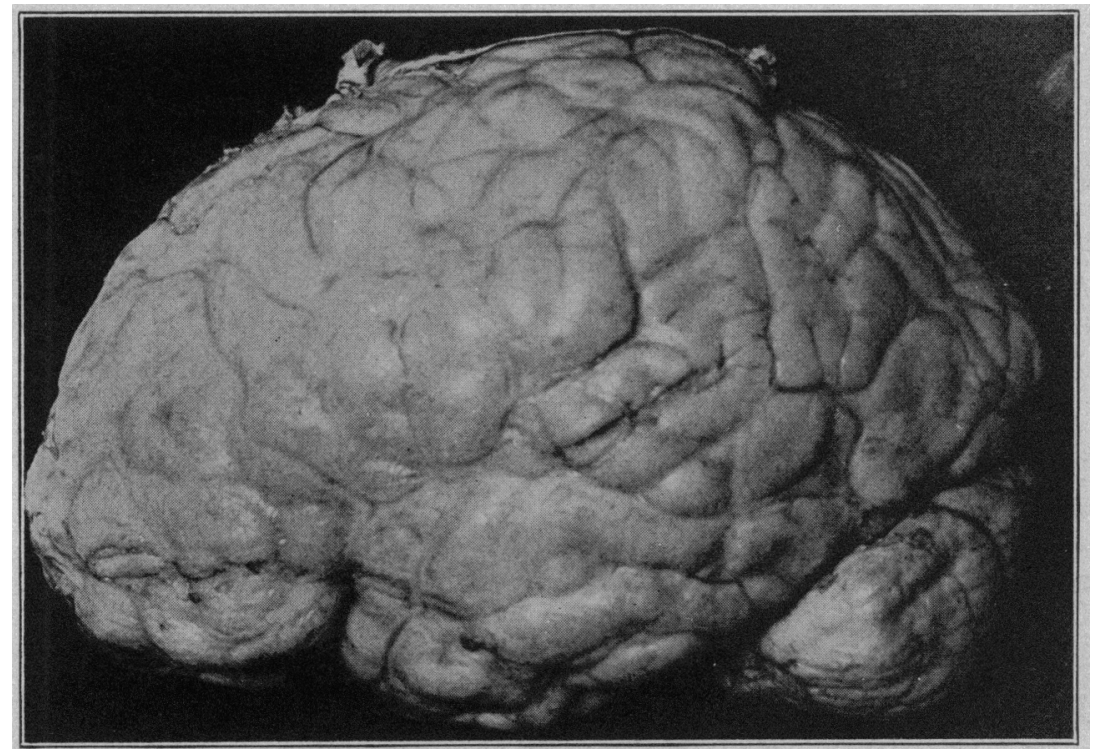

Fig. 1.-Photograph of left surface of brain.

large, irregular shaped, with a small amount of chromatin material. These cells are not numerous (Fig. 4).

What is particularly striking in a cursory examination is that the cellular infiltration about the blood vessels is markedly less dense than elsewhere; this is especially true of the veins (Fig. 3). The mononuclear cells are about equally distributed in the perivascular areas and elsewhere. In the densely cellular areas are numerous small nuclear bodies from 3 to 4 microns in diameter, quite uniformly stained, with no darker stained chromatin masses.

The most common cells besides the polymorphonuclears are plasma-like, with pale staining, more or less vacuolated cytoplasm. The nuclei are large, round, eccentric in position, usually one or two nucleoli, and very little other chromatin.

There is remarkably little perivascular infiltration in the cortex, and a surprising decrease about the blood vessels in the membranes.

The area at the base of the cerebellum, which in gross appeared as pus, showed cellular infiltration as described above. Despite a careful search, no definite bacilli could be found in 10 micron sections. 
Kidneys: Markedly dilated convoluted tubules; capillaries congested in cortex, glomeruli only slightly enlarged. Convoluted tubules show granular epithelium, nuclei stain quite well; occasional red blood cells in tubules; no casts, but occasional desquamated epithelial cells.

Spleen: Shows quite large nodules, rather increased vascularity. The splenic sinuses are large, dilated, empty. The pulp shows many red blood cells.

Mesenteric Lymph Nodes: Large, the one sectioned measuring about $1 \mathrm{~cm}$. in diameter, with a very large artery and vein in the center. Most of the section shows lymphoid tissue with some increase of connective tissue and congested vessels. One large area, macroscopically visible, is necrotic, has numerous polymorphonuclear cells with small necrotic nuclei, and pink staining fibrous debris.

Liver: Shows quite large sinuses with numerous red blood cells. Alout the central veins, the hepatic cells appear smaller, but stain well.

We did not have all the mediums necessary for the proper isolation of typhoid bacilli, so we sent a subculture of the spinal fluid taken the day before death to Dr. Noble Sherwood, whose report was, in part, as follows:

"The culture as received contained two organisms, a gram-negative rod and a gram-positive spore producer. I plated them immediately, and beg to report the gram-negative rod as a slightly atypical strain of $B$. typhosus. Its reaction to the gram stain is typical, but the motility is so slight as to be negligible. I have repeatedly observed that freshly isolated strains of $B$. typhosus were frequently either nonmotile, or slightly motile for several generations after isolation, and then they would suddenly become actively motile. This is more especially true when organisms have been isolated from the blood stream, rather than from feces.

"The strain sent in by you does not produce any acid or gas in saccharose; this is typical. It gives acid, no gas in dextrose and manuite, these reactions are typical. It seems to show a tendency to acidify lactose; this is an atypical reaction. However, this strain is identical in its action on lactose as in a European strain of $B$. typhosus we have under observation. The reaction in gelatin shows no liquefaction, which is typical for B. typhosus.

"Now, the agglutination test with a polyvalent antityphoid serum shows agglutination in dilution of $1: 3,000$. The other laboratory strains, such as the New York Board of Health and the Bender strain, show agglutination in $1: 8,000$ and $1: 10,000$ dilutions. We have isolated quite a number of strains, however, that show agglutination in dilutions higher than your strain and less than the other strains.

"I feel no doubt that the organism you are working with is B. typhosus and apparently quite similar to the European strain which we have been working with."

To verify these findings, we also sent a subculture to Dr. F. J. Hodges, Department of Pathology, Washington University Medical School, St. Louis, and append part of his report. (Unfortunately, both specimens sent seem to have been contaminated, as in our earlier cultures we found only one gramnegative short bacillus. Our later cultures here were contaminated by a gram-positive, large, thick bacillus.)

"There are three organisms in the original cultures. One a gram-positive spore former overlooked in the first smears because of the great preponderance of gram-negative bacilli of two morphologic types. One gram-negative bacillus is very short and fat. The other, recovered from isolated colony on agar plate, is nearly twice as long, and little, if any, wider. The gram-positive organism was discarded. Both gram-negative strains gave typical sugar results for typhoid (when mixed with the gram-positive spore former, the sugar reactions were atypical) and both gram-negative strains are agglutinated by the stock typhoid serum. In cross agglutination tests, Para 'A' and Para ' $\mathrm{B}$ ' and the dysenteries, the results are widely different for the two organisms, indicating that both morphologically and serologically we have here two types of typhoid bacillus. 
"These two types labeled and sent to us as B I and B II, agglutinated the stock typhoid serum at $1: 6,000$ and $1: 24,000$, respectively, B II was agglutinated by various low dilutions of both Para A and B serum, and by Flexner's serum, but neither by Shiga bacillus serum in any concentration."

We had begun a thorough collection of the reported cases of typhoid meningitis, intending only to summarize the purulent cases since Cole's paper. ${ }^{1}$ Then we found Bayne-Jones' ${ }^{2}$ article, published in 1917, although apparently prepared in 1915. We have found only a few cases that he has not noted, and have completed the table for comparison with Cole cases.

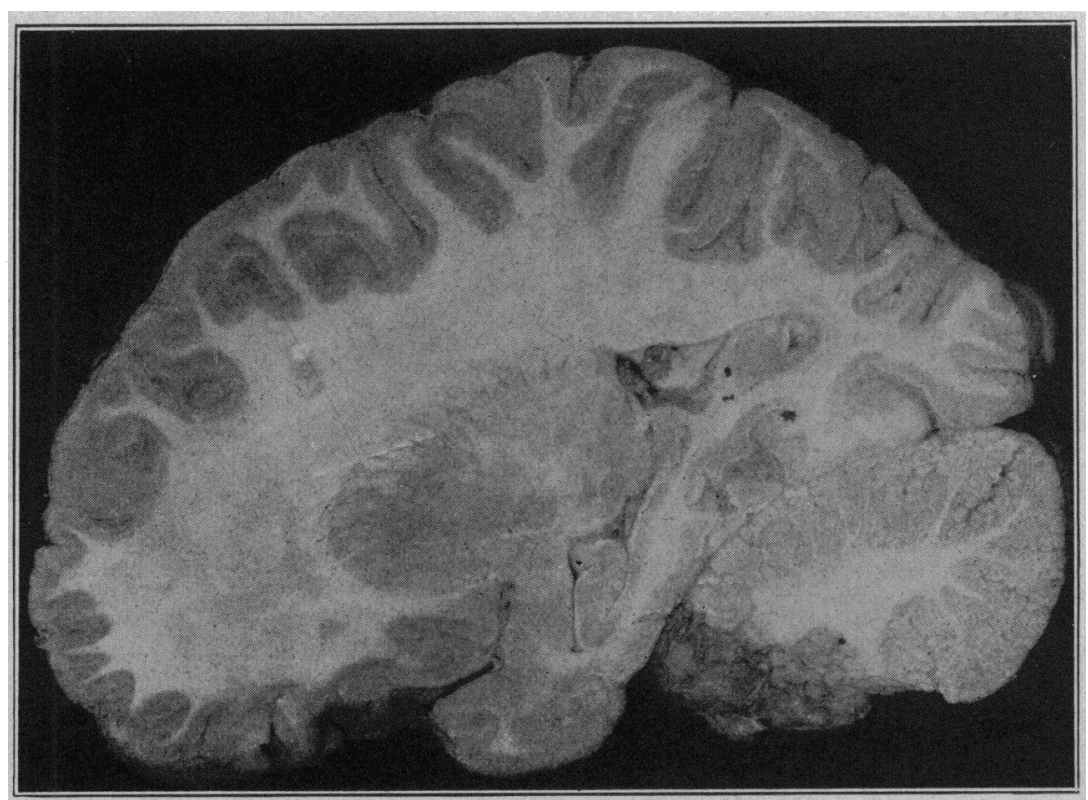

Fig. 2.-Photograph of a cross section of the left half of the brain.

McCrae ${ }^{3}$ cites a case of typhoid fever, diphtheria and acute encephalitis. The diphtheria bacillus was found early in the disease, but disappeared after a few lays; the blood culture gave a pure typhoid growth and the Widal was positive. The necropsy report showed a reddish sphenotemporal lobe, and thrombosed vessel in this part, but, unfortunately, no cultures were made from the brain.

Schwartz reviewed some of the cases reported by Cole, and thinks that contamination of the spinal fluid may take place through the blood which is known to contain the B. typhosus. He would exclude these

1. Cole, R.: Typhoid Meningitis. Johns Hopkins Hosp. Rept. 12:299, 1904.

2. Bayne-Jones, S.: Typhoid Meningitis, Report of a Case, Am. J. M. Sc. $154: 55,1917$.

3. McCrae, J.: Two Unusual Occurrences in Typhoid Fever, Acute Encephalitis and Perforation of the Sigmoid Flexure, Lancet 1:712, 1905. 


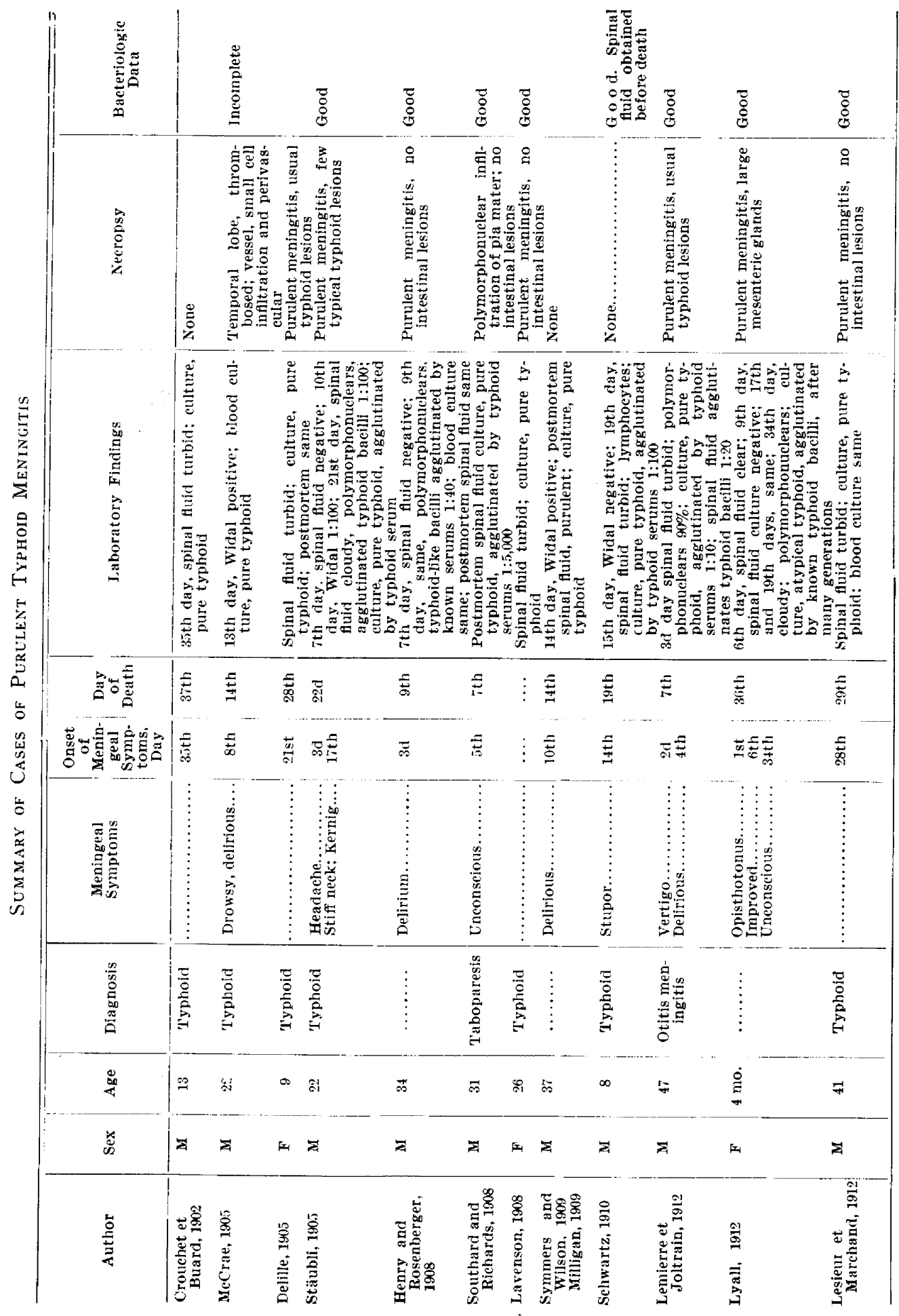




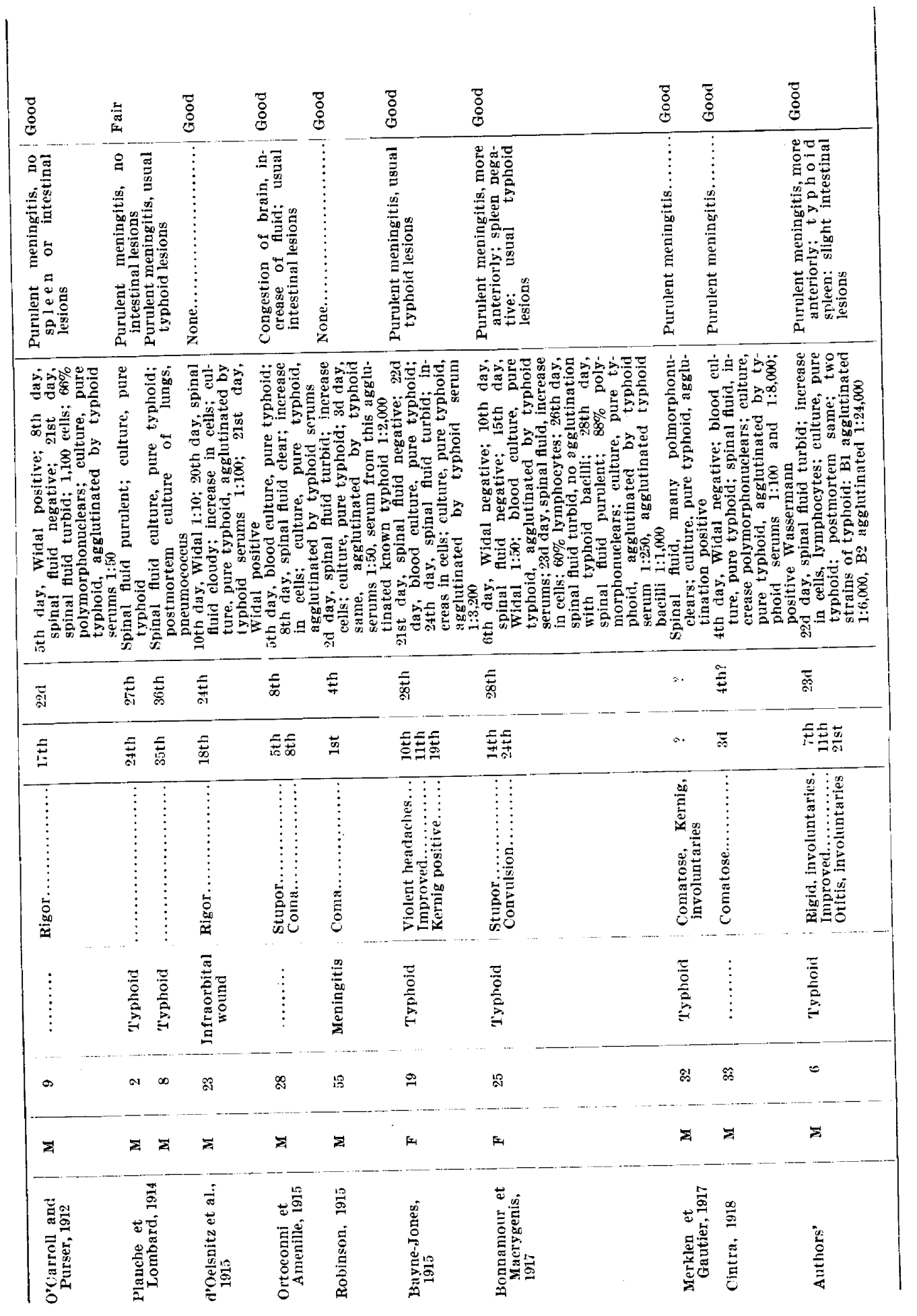


cases where such contamination during spinal puncture may have occurred.

Lyall ${ }^{4}$ regarded Neuman and Schaffer's ${ }^{5}$ case as being one of true purulent typhoid meningitis. Of course, the now known laboratory tests were not applied, but it appears that their tests were conclusive, since only the potato culture was questionable. In Lyall's own case, the culture showed an atypical typhoid, in that only after several generations was it motile, and then only slightly. Then, only, was it agglutinated by known typhoid serums, but best by an homologous serum which agglutinated also known typhoid bacteria.

O'Carroll and Purser ${ }^{6}$ noted Osler's eleven cases of central nervous system lesions in two thousand cases of typhoid, and Curschman's five in his own experience, but, unfortunately, bacteriologic examinations were not complete. O'Carroll found fifteen reported cases where typhoid bacilli alone caused a meningitis, and estimated that there are not more than thirty cases in all. They believed that the purulent condition of the brain is only an advanced stage of an edema often described-with which we, of course, agree.

I)'Oelsnitz ${ }^{\top}$ and Amenille ${ }^{s}$ described cases with increased cell count in the spinal fluid, but no turbidity nor increased pressure, and the latter briefly described another case which cleared up for them after the postmortem examination.

An astonishing finding to us, and one already noted by others (Fernet ${ }^{9}$ ) is the frequent lack of the usual typhoid lesions, although many of the cases showed positive Widal and blood cultures. In six cases here recorded, special mention was made that little or no intestinal lesions were present; in some, the spleen was quite normal. In our case, there was no evidence of intestinal lesion, except one inch above the ileocecal valve. The mesenteric glands and spleen were markedly enlarged. In our case, too, the marked dilatation of ureters and urinary tubules with no apparent cause was noted. Of course, we must admit that the intestinal lesions may have healed. Against this theory in many cases, is the relatively short course of the disease.

4. Lyall, H. W.: Meningitis in an Infant Caused by the Typhoid Bacillus, J. Med. Res. 22:457, 1912.

5. Neuman, H., and Schaeffer, R.: Zur Aetiologie der eitrigen Meningitis, Virch. Arch. $109: 477,1887$.

6. O'Carroll. J., and Purser, F. C.: On a Case of Meningitis Due to Bacillus Typhosus, Tr. Roy. Soc. Med. Ireland 30:108, 1912.

7. d'Oelsnitz, M., Bourcart, G., and Ronchese, M. A.: Un cas de méningite cérébro spinale éberthienne, Bull. et mém Soc. méd. d. hôp. de Par. 39:276, 1915.

8. Ortoconni, A., and Amenille, P.: Accidents méninges précoces dans la fièvre typhoide, Bull. et mém. Soc. méd d. hôp. de Par. 31: 187.

9. Fernet. Ch.: Méningite typhoïde par bacille d'Ełerth, Bull. et mém. Soc. méd. d. hôp. de Par., 1891, p. 361. 
In several cases were noted-and this is particularly true in Bonnamour and Macrygenis ${ }^{10}$ and our cases - that the anterior portion of the brain showed a more marked purulent condition than the posterior. This is evident even in the photograph, but was especially noted at the postmortem table. However, a collection of pus below the cere-

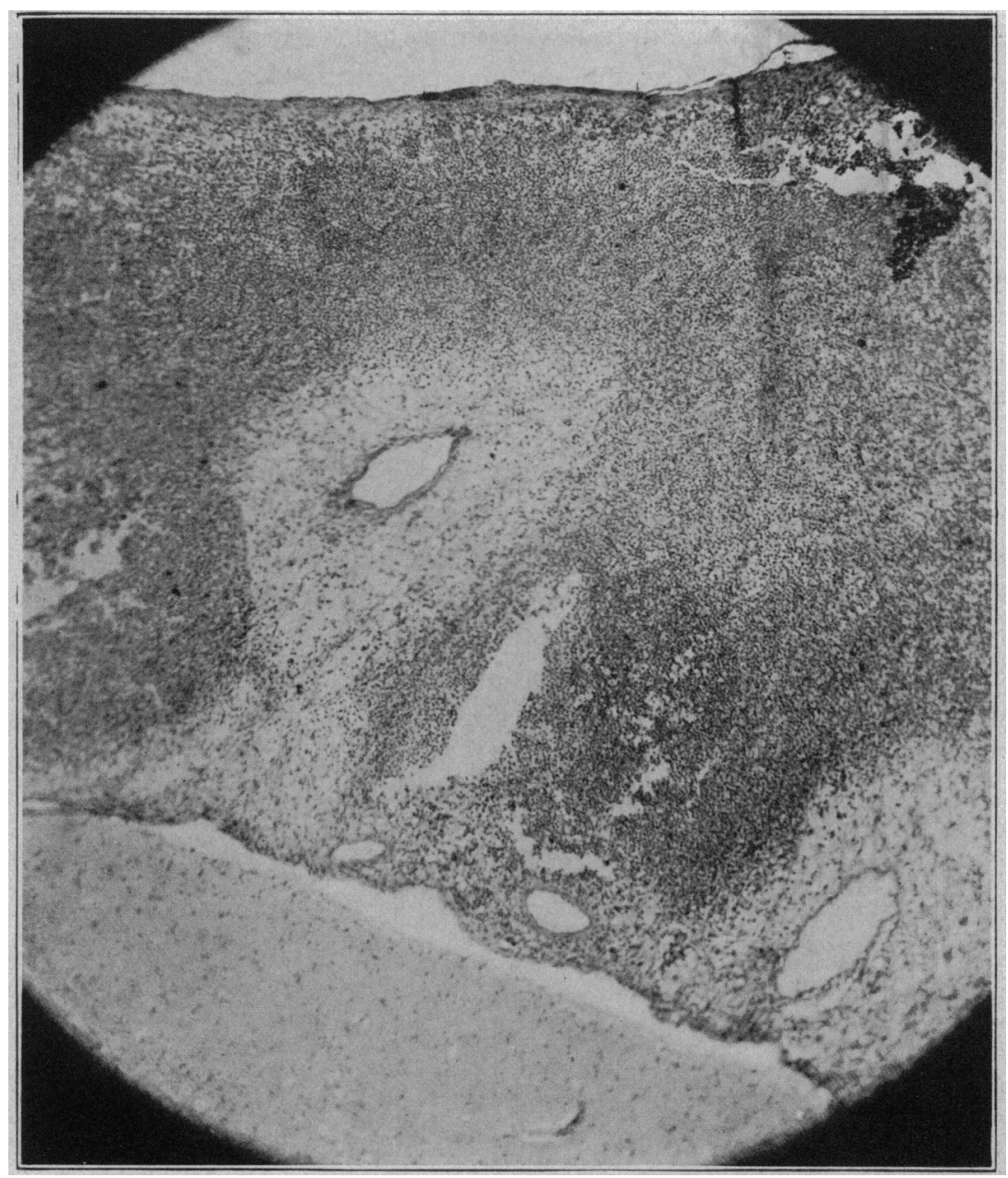

Fig. 3.-Photograph of a 10 micron section of the meninges over the frontal lobe (ocular, 4 ; objective, 3 [Leitz]).

bellum was also noted. The ventricles in our case, differing from others, were not enlarged, but contained a turbid fluid on examination.

10. Bonnamour, S., and Macrygenis, A.: Méningite aiguë purulente eberthienne au cours d'un fièvre typhoïde. Presence du hacille d'Eherth dans le liquide céphalo-rachidien, Lyon méd. 126:397, 1917. 
Lesieur and Marchand ${ }^{11}$ were able to find only nine cases in the literature in which the typhoid bacillus had been grown from the spinal fluid before death. Fifteen of the cases reported herein specifically state that the typhoid organism was isolated during life from the spinal fluid. Cole's ${ }^{1}$ table does not state whether culture was made before or after death. In some, apparently, they were made at the postmortem; in one, on the day of death; in others, the time is not quite clear. However, we have reviewed other cases, not here tabulated, in which the typhoid bacillus was obtained from the spinal fluid where no purulent condition supervened, and where death did not follow. These probably belong to Cole's serous meningitis cases. Cole, in thirteen cases of serous meningitis, shows that in six the typhoid bacillus was grown from the spinal fluid in pure culture during life, and that it was grown from the others after death. Therefore, quite occasionally, the typhoid bacilli may be grown, although there is no change in the gross appearance of the spinal fluid.

In only six cases did Lemierre and Joltrain ${ }^{12}$ find a primary typhoid meningitis - or rather, one apparently not following intestinal typhoid - as their case showed an otitis media very early, although, as they stated, the meningitis may not have been secondary to the otitis. Apparently, two other cases in our table were either primary or secondary to a typhoid other than intestinal - one of them to an infraorbital war wound. In several of the cases occurring in soldiers, no clear history was obtainable. These may have had a primary abdominal infection.

Lemierre and Joltrain also point out the peculiarity in meningitis cases of the spinal fluid agglutinating the organism. They believe that this is exceptional, as it has been stated that agglutinins, although present in blood, have not been observed in the spinal fluid. In their case, the spinal fluid agglutinated the organism grown from it, and also laboratory strains. Bayne-Jones ${ }^{2}$ states that in serous cases, the spinal fluid contains agglutinins for B. typhosus.

Several investigators found a clear fluid in early lumbar punctures, and later, turbidity and increased pressure. In only very few was a definite cell count reported. O'Carroll and Purser ${ }^{6}$ and Lemierre and Joltrain ${ }^{12}$ reported relatively high polymorphonuclear leukocytes in their earlier counts, although in the latter, a later count showed an increase of small round cells. Bonnamour and Macrygenis ${ }^{10}$ reported

11. Lesieur, C., and Marchand, M. J.: Etat méningé au cours d'un fièvre typhoide. Evolution bénigne apres la ponction lombaire, Bull. et mém. Soc. méd. d. hôp. de Par. 34:785, 1912; Ibid., 780.

12. Lemierre, A., and Joltrain, E.: Méningite purulente Eberthienne début par symptomes d'otite aiguë, Bull. et mém. Soc. méd. d. hôp de Par. 34: 581. 1912. 
in their first count a predominance of lymphocytes and in a later count 80 per cent. polymorphonuclears. Unfortunately, no differential count was made in either of our counts, but there was noted a predominance of mononuclears.

MacCalltm ${ }^{1: 3}$ carefully described the minute pathology of typhoid meningitis. Others ${ }^{14}$ have found in general the same results as MacCallum. Our sections do not show the congestion of the veins, nor the blocking of the arteries by a cellular infiltration of the vessel wall and an endarteritis, as MacCallum appears to have found. In fact, we see in our sections that the cellular infiltration is less marked about the blood vessels than elsewhere, especially about the veins. It is possible that we are dealing with a more recent meningeal involvement than MacCallum had, for Cole noted that in that case meningeal symptoms were marked for one week before death with the bacilli already in the spinal fluid.

In our table, which includes twenty-three cases, the ages of the patients vary from 4 months to 55 years. There are eighteen males and five females. Cole's patients varied in age from 4 to 46 years, with five males and three females, three under 20 years, two over 40 . Our table shows nine patients under 20 and three over 40 years of age.

Symptoms of meningeal irritation are so frequent in typhoid cases that it is clifficult to judge when the real meningitis begins. If daily spinal punctures are made, of course, the date of a turbid fluid might be an index. So far, we know of no definite symptom that can be taken as an index of a purulent meningitis. In our case, were an early restlessness. involuntary voiding of urine and feces, and rigidity an index of purulent meningitis? Of meningeal irritation, of course! Or was this the second stage, after the gallbladder involvement, with otitis, involuntary voiding of urine and feces and convulsions? We have taken the latter view. And so, in other cases, we have taken what scemed to be the final meningeal flare-up before death as the stage of onset of purulent meningitis. Judging thus, we find its onset varies

13. MacCallum. W. G.: The Pathological Anatomy of Meningitis Due to Bacillus Typhosus, Johns Hopkins Hosp. Rept. 12:411, 1904.

14. Cintra, L.: Meningite purulenta com bacillo de Elerth isolacio do liquido cephalo-rachiano, Ann. Paulistas de méd. e Cir. 9:64. 1918. Crouchet and Buard: Sur un cas de méningite cérébro-spinale typhique, aver présence du bacille d'éberth dans le liquide cépholo-rachidien, Ga\%. helol. d. sc. méd. de Bordeaux, 1902. Delille: Pediat. prat. Lille 3:89, 1905. Lavenson, R. S.: Univ. Penn. Med. Bull. 21:55, 1902. Merklen and Gautier: Méningite aiguë éberthienne à forme purulente. Présence du bacille typhique clans le liquid céphalo-rachidien, Presse méd., Jan. 22, 1917, p. 51. Milligan, E. H. M.: Isolation of the Typhoid Bacillus from the Spinal Fluid from a Case of Typhoid with Cerebrospinal Symptoms, Brit. M. J. 1:1295, 1908. Nietter, A.: Ueber den Nachweis vom Typhushazillen. der Zerelorospinalflüssigkeit bei typhus Abdominalis, München. medl. Wchnschr. 55:1009, 1 908. 
from the first to the thirty-fifth day. Symptoms lasted then, for from one to ten days, some showing convulsions, but many with other meningeal symptoms of involuntary sphincteric relaxation, vomiting, intense headache, contraction of various muscles, frequently of the hands and face. Cole found that symptoms began late. from the second to the fifth week, and lasted for from two to five days.

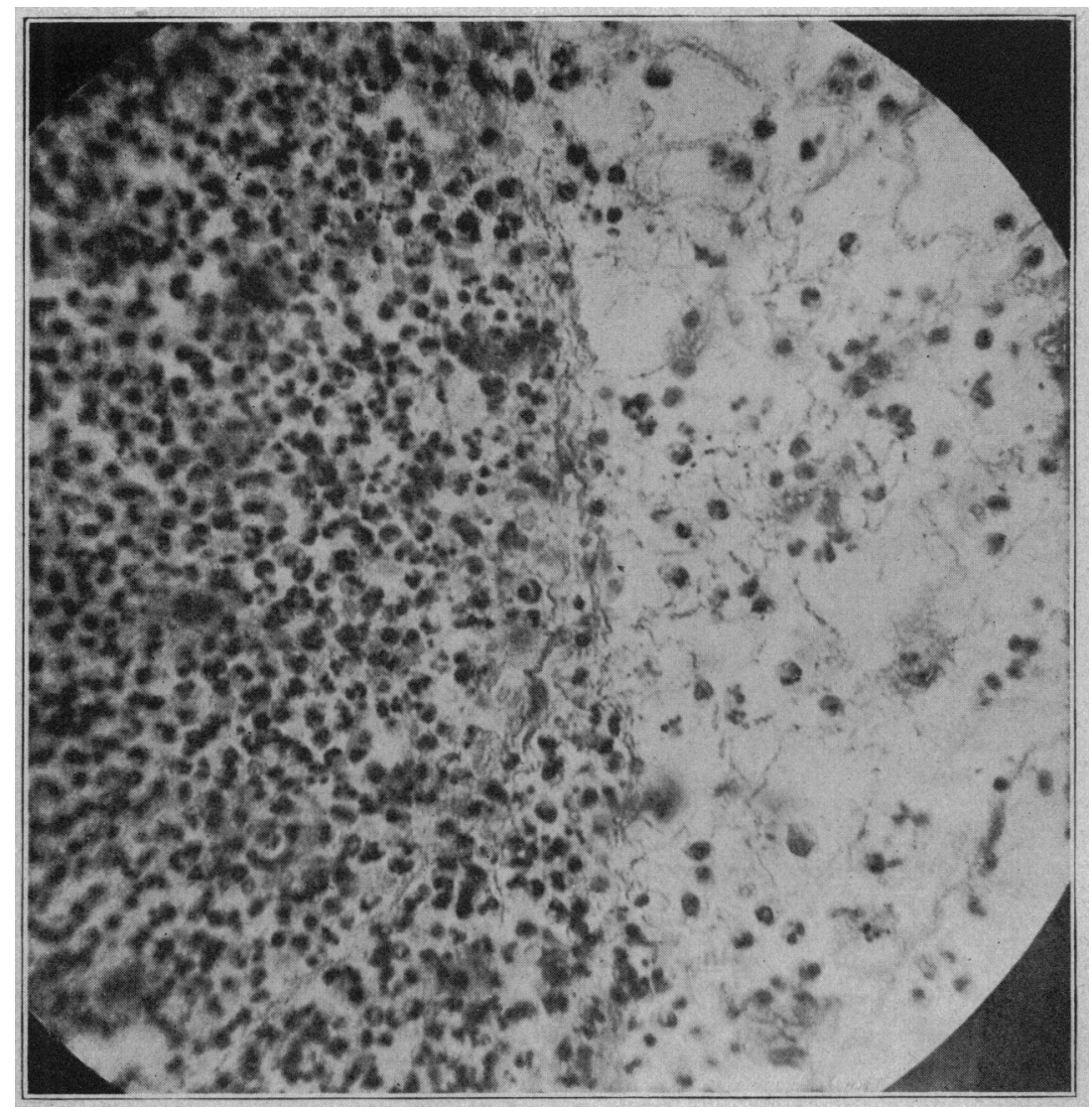

lig. 4.-Photograph of the meninges near a blood ressel showing perivascular infiltration and the denser infiltration away from the blood vessels (ocular, 4: objective, 6).

We have not accepted two of the cases put in Bayne-Jones report, one by Gurd and Nelles ${ }^{15}$ which seems to have been an abscess above the dura, following an injury, and not a meningitis, even though

15. Gurd, F. B., and Nelles, T. B.: Intracranial Abscess Due to the Typhoid Baciltus, Ann. Surg. 47:4, 1908. Henry, J. N., and Rosenberger, I. C. R.: Purulent Cerehrospinal Meningitis Cansed by the Typhoid Bacillus without the Usual Intestinal Lesions of Typhoid Fever, Anı. J. M. Sc. 135:240, 1908. 
typhoid bacilli were isolated. The other (Raymond and Siccard ${ }^{16}$ ) was an infection localized in the lumbar region, from which pus and a pure culture of typhoid was obtained. After laminectomy, the patient recovered. To us, it seems that purely localized typhoid infection of the meninges, especially with recovery, should not be included.

The prognosis, as shown by our table, is very bad. Excepting the two cases, quoted above, neither of which is included in our table, there have been no recoveries. It is to be remembered, that in thirteen cases of serous meningitis Cole found only one recovery. Although Bayne-Jones does not give the number of recoveries from serous meningitis in his table, he quoted Claret and Lyon-Caen as having found eight recoveries in thirteen cases. Cole showed that there were no recoveries in his fourteen cases of purulent meningitis.

The question of treatment may seem out of place in a disease which has been so uniformly fatal. Possibly prophylaxis offers the best hope. Lemierre and Joltrain, ${ }^{12}$ after removal of spinal fluid, introduced electrargol, evidently with no results. But since some recoveries occur in some serous cases, and some have noted a marked improvement following lumbar puncture, repeated punctures may help. Even in some cases with amelioration of symptoms after puncture, which usually showed clear fluid, a purulent fluid formed later and death supervened.

To us, it seems that a purulent spinal fluid, with cultures showing typhoid bacilli, is proof enough of a typhoid meningitis. Of course, this does not mean that necropsies should not be obtained; nor that other organisms may not be responsible. But even in mixed infections, except for statistical reports, what does it matter if other organisms are present?

Purulent typhoid meningitis has been noted usually following abdominal typhoid, but also as secondary to other typhoid as witness one otitic and one infraorbital wound.

Cole reported fourteen cases and Bayne-Jones eighteen. We have ruled out two of the latter and added seven more. All gave pure typhoid cultures from the spinal fluid, most of them before death. In all these cases the organism has been isolated with a fair degree of accuracy. All cases noted have terminated fatally.

16. Raymond, F., and Siccard, J. A.: Epidurite purulente lombaire a bacilles d'Eberth dans la convalescence d'une fièvre typhoïde. Paraplégie. Ponction lombaire, Bull. et mém. Soc. méd. d. hôp. de Par. 22:860, 1905. Robinson, J. E. : Case of Primary Typhoid Meningitis, South. M. J. 8:37, 1915. Southard, E. E., and Richards, E. T. F.: Typhoid Meningitis, J. Med. Res. 19:513, 1908. Staubli, C.: Meningismus typhosus und Meningotyphus, Deutsch. Arch. f. klin. Med. 82:90, 1905. Symmers and Wilson: J. Path. \& Bacteriol. 13:251, 1909 (quoted from Bayne-Jones). Stühmer, A.: Typhusbazillen in der Zerebrospinalfüsigkeit, München. med. Wchnschr., 1911, p. 357. 